Document downloaded from:

http://hdl.handle.net/10251/136499

This paper must be cited as:

Ballesteros Pérez, P.; González-Cruz, M.; Cañavate-Grimal, A. (2012). Mathematical relationships between scoring parameters in capped tendering. International Journal of Project Management. 30(7):850-862. https://doi.org/10.1016/j.ijproman.2012.01.008

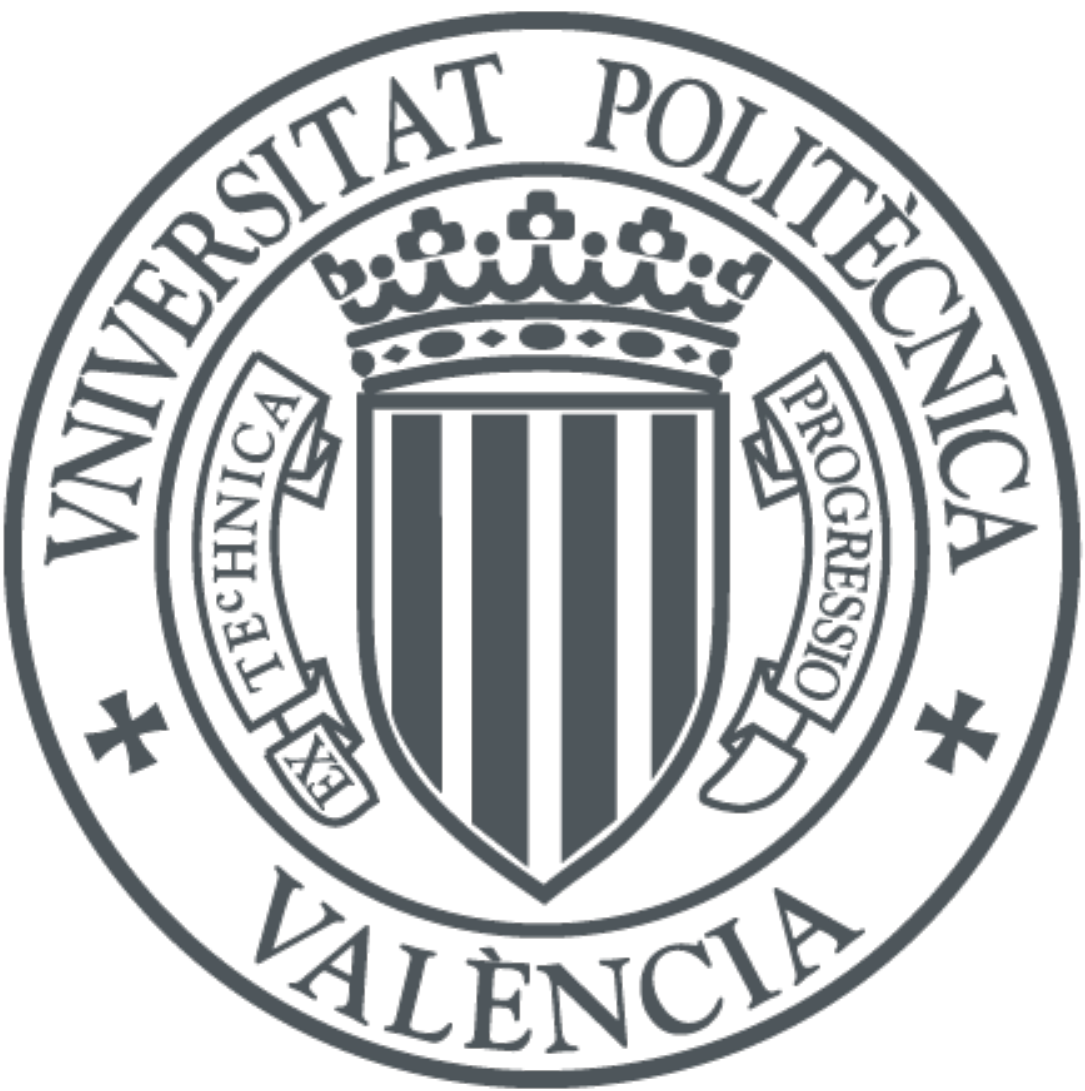

The final publication is available at

http://dx.doi.org/10.1016/j.ijproman.2012.01.008

Copyright Elsevier

Additional Information 


\title{
MATHEMATICAL RELATIONSHIPS BETWEEN SCORING PARAMETERS IN CAPPED TENDERING
}

\author{
Additional Information: \\ Bidding (Contractors); Managing Proposal \\ Industry and Sector Specific: Engineering and Construction.
}

\section{Authors:}

Ballesteros-Pérez, $\mathrm{P}^{\mathrm{a}}$; González-Cruz, $\mathrm{M}^{\mathrm{a}} \mathrm{C}^{{ }^{\mathrm{b}}}{ }^{\text {; Cañavate-Grimal, A. }}{ }^{\mathrm{c}}$

\footnotetext{
a Head of Construction studies in Depuración de Aguas del Mediterráneo SL (Spain).

$\mathrm{PhD}$. and Msc. in Civil engineering. IPMA certified Project Manager (C level)
}

Depuración de Aguas del Mediterráneo S.L. C/Guglielmo Marconi 11, 2nd, office 19 Parque Tecnológico 46980 Paterna (Valencia, Spain)

Part-time Lecturer in Departamento de Ingeniería del Terreno. Escuela Técnica Superior de Ingenieros de Caminos, Canales y Puertos. Universitat Politècnica de València. $C^{\circ}$ de Vera s/n, 46022 Valencia, Spain

Phone: +34 902881510 (ext.: 366) Fax: +34 963531225 .

E-mail : pabbalpe@trr.upv.es

b Lecturer in Departamento de Proyectos de Ingeniería. Escuela Técnica Superior de Ingenieros Industriales. Universitat Politècnica de València. $C^{\circ}$ de Vera s/n, 46022 Valencia, Spain

$\mathrm{PhD}$. Industrial Engineering. IPMA certified Project Manager (C level)

Phone: +34 963879866 (ext.:75654 ) Fax: +34 963879869 (ext.:79869 ).

E-mail: $\underline{\text { mcgonzal@dpi.upv.es }}$

Corresponding author

c Lecturer in Departamento de Ingeniería de la Edificación y Producción Industrial. Escuela Superior de Enseñanzas Técnicas (ESET). Universidad CEU San Pablo. Calle de San Bartolomé 55. 46115. Alfara del Patriarca, Valencia. Spain.

MSc. Civil Engineering \& Geotechnical Engineering

Phone: +34 961369000 Fax: +34 961300977

E-mail: antonio.canavate@uch.ceu.es 


\title{
MATHEMATICAL RELATIONSHIPS BETWEEN SCORING PARAMETERS IN CAPPED TENDERING
}

\begin{abstract}
Mathematical relationships between Scoring Parameters can be used in Economic Scoring Formulas (ESF) in tendering to distribute the score among bidders in the economic part of a proposal.
\end{abstract}

Each contracting authority must set an ESF when publishing tender specifications and the strategy of each bidder will differ depending on the ESF selected and the weight of the overall proposal scoring.

This paper introduces the various mathematical relationships and density distributions that describe and inter-relate not only the main Scoring Parameters but the main Forecasting Parameters in any capped tender (those whose price is upper-limited).

Forecasting Parameters, as variables that can be known in advance before the deadline of a tender is reached, together with Scoring Parameters constitute the basis of a future Bid Tender Forecasting Model.

Keywords: bid; tender; auction; construction; scoring system.

\section{Introduction}

Competitive bidding is a transparent procurement method in which bids from competing contractors, suppliers, or vendors are invited by openly advertising the scope, specifications, and terms and conditions of the proposed contract as well as the criteria by which the bids will be evaluated.

Research in the area of competitive bidding strategy models has been in progress since the 1950s (Deltas \& Engelbrecht-Wiggans, 2005; Dikmen et al., 2007; Engelbrecht-Wiggans, 1980, 1989; Harstad \& Saša Pekec, 2008; Lo et al. 2007; Naoum, 1994; Näykki, 1976; Rothkopf \& Harstad, 1994; Rothkopf, 1969; Ye et al., 2008). Competitive bidding aims at obtaining goods and services at the lowest prices by stimulating competition, and by preventing favoritism. Competitive bidding strategy models have been developed to predict the probability of a bidder winning an auction (Engelbrecht-Wiggans, 1980; Näykki, 1976). However most of these models are based on the theory of Games, Decision Analysis and Operational Research and are difficult to apply to real-world business contexts because of 
the complex mathematical formulations used in the models (Engelbrecht-Wiggans, 1980; Harstad \& Saša Pekec, 2008; Rothkopf \& Harstad, 1994).

Because of the multiple technical and financial criteria involved in public tendering (Engelbrecht-Wiggans, 1980; Fayek, 1998; Harstad \& Saša Pekec, 2008; Näykki, 1976; Rothkopf \& Harstad, 1994; Skitmore \& Drew, 2001; Skitmore, 2002, 2004), there is still a need for the development of new tools that help decision makers to improve the selection process of candidate contractors (Watt et al., 2009).

A new practical tool was presented in Ballesteros-Pérez et al, 2011 that can help potential bidders improve their competitive bidding strategies and increase their chances of winning a contract. This tool, called iso-Score Curves Graph (iSCG), is the first out of four graphs that will enable bidders to place their bids using simple statistical procedures based on previous bidding experiences.

This paper describes the relationships between the main variables of the model called "Scoring Parameters (SP)". These variables use Economic Scoring Formulas (ESF) to distribute the points of the economic section in a tender among the different economic bids proposed by the bidders. These mathematical relationships can be graphically represented using an iSCG to observe the goodness of fit of the statistical relationships and deviations in a historical database of past tenders. These mathematical relationships play an essential role in the tendering process since, once one of the Scoring Parameters (SP) is known the other parameters can be easily calculated.

Additionally, certain "Forecasting Parameters" (FP) closely related to the SPs can be calculated before the deadline of a tender. In this connection, the estimation of the value of an FP allows determining which competitors' Bids can be statistically expected (through SP Forecasting).

\section{Background}

An extensive literature exists about the theory of auctions and competitive bidding for contract tendering. Most of the models, however, are based on theoretical assumptions that are difficult to apply to real cases (Skitmore, 2008). Bidding theory and strategy models (see Stark and Rothkopf, 1979, for an early bibliography) frequently make use of the so-called 'the statistical hypothesis' as auction bids are assumed to contain statistical properties such as fixed parameters and randomness (Skitmore, 2002).

The first studies (e.g., Friedman, 1956) assumed that each bidder drew bids from a probability distribution unique to that bidder, with low-frequency bidders being pooled as a special case. Pim (1974) analyzed a number of projects awarded to four USA construction 
companies. His study indicated that the average number of projects awarded is proportional to the reciprocal of the average number of bidders competing - the proportion that would be expected to be won by pure 'chance' alone. That suggested an extremely simple 'equal probability' model in which the expected probability of entering the lowest bid in a k-size auction, that is, an auction in which $\mathrm{k}$ bidders enter bids, is the reciprocal of $\mathrm{k}$.

McCaffer and Pettitt (1976) and Mitchell (1977) assumed non-unique and homogeneous probability distributions, enabling a suitable distribution shape to be empirically fitted (uniform, in the case of McCaffer and Pettitt) and the derivation of other statistical distributions based on an assumed (normal) density function.

Since then, different models have been developed to calculate the probability, $\operatorname{Pr}(m)$, of individual contestants winning a bidding auction (Skitmore et al., 2007); some of such models are Friedman's (Friedman, 1956), Gates' (Gates, 1967), Carr's (Carr, 1982) and Skitmore's (Skitmore, 1991) models, among others. These models are based on the same statistical model differing only in their method of parameter estimation.

In the context of construction contract bidding, it is difficult to collect the necessary data of each bidder for predictions to be effective (Skitmore, 2002). Besides, Skitmore showed that the homogeneity assumption (Skitmore, 1991) was not a valid approach for predicting the probability of lowest bidders (Skitmore, 2002) and Runeson and Skitmore (1999) criticized the use of heterogeneous models based on fixed parameters.

The mathematical relationships described in this paper can be used by bidders to represent historical bidding datasets as a way of inferring patterns of competitors' behavior. Unlike other models based on probabilistic description of groups of single bidders, the proposed Bid Tender Forecasting Model or BTFM hereinafter (which will be completely described in upcoming publications) describes group patterns while bidding.

The proposed model solves the major problems encountered in previous models as it allows beneficiaries to (1) Study bidding behaviors with a significant small database compared to previous works; (2) Forecast the probability of obtaining a particular position among competitors, and (3) Analyze time variations between tenders (Skitmore \& Runeson, 2006).

Furthermore, other formal and analytical risk models have recently been developed to prescribe how risk is to be incorporated into construction bids (Hartono \& Yap, 2011; Mohamed et al., 2011; Oo et al., 2008), in practice, price risks are usually excluded from the final bid to improve competitiveness (Laryea \& Hughes, 2011). Future works about the BTFM will consider risk issues through the analysis of the different probability levels resulting from the combination of potential bids. Nevertheless future research will have to be developed in order to study the causes of those parameter variations. 
However, due to the lack of space needed to describe the whole BTFM, in this paper only the major mathematical basis will be shown. The equations shown later, combined with the first model's tool: the iso-Score Curves Graph (iSCG) (Ballesteros-Pérez et al, 2011), will enable the bidding data and their more likely upcoming Bidders' Bid behaviors to be represented in a convenient manner.

\section{Basic definitions}

This work uses the Spanish tendering terminology as the study was carried out in Spain, although some new terms are included. The BTFM described in this paper has been applied to capped tenders, that is, tenders upper-limited to the contracting authority estimate stated in the tender specifications.

However, the expressions shown below are not only restricted to this type of tender. If the main mathematical relationships between SPs and FPs are re-written to leave out the tender amount/price $(A)$, the equations shown below could also be used for both capped and noncapped tenders, since this latter type of tender is the most common in many countries

For the sake of clarity, some terms used in this paper are going to be previously defined (see Appendix A for further information).

"Economic Scoring Formula" (ESF) refers to the mathematical expressions used to assign numerical scores to each bidder from its bid price expressed on a monetary-unit basis. ESF comprises the mathematical operations that provide the score and the mathematical expression that determines which bids are abnormal or risky (Abnormally Low Bids Criteria (ALBC). ALBC has received much less attention in the literature than the analysis of contractors' bidding behaviors (Chao \& Liou, 2007).

"Scoring Parameter"(SP). SPs are the variables used in ESFs. They are calculated from the distribution of the bids participating in a tender contest.

"Bidder's Drop (D). It is the discount or bid reduction in the initial price of a contract (A) submitted by a given contractor $i$ for a particular capped tender. It is mathematically expressed as:

$$
D_{i}=1-\frac{B_{i}}{A}
$$

Where $D_{i}$ is the Drop (expressed in per-unit values) of bidder " $i$ ", $B_{i}$ is the Bid (expressed in monetary values) of bidder " $i$ ", and $A$ is the initial Amount of money (in monetary values) of the Tender (generally set by the Public Administration or contractor in many countries).

In Spanish tendering practice, when referring to bid amounts, it is usual to use a discount on the contract value A. This discount is called 'baja' in Spanish, meaning literally fall or drop. 
This term has been translated merely as 'Drop' because no similar concept has been found in the international bibliography.

The ESF scores are obtained either using the bidders' bids $\left(B_{i}\right)$ in monetary values or converting Bidders' bids into Drops $\left(D_{i}\right)$ in per-unit values. However, for the comparison of bids in different bidding processes with different initial bid amounts $(A)$ for each tender, it is preferable to use Drops $\left(D_{i}\right)$ than Monetary-based Bids $\left(B_{i}\right)$.

The SPs have been classified into two groups: Primary SPs and Secondary SPs. Primary SPs are base-line or reference parameters from which the Secondary SPs are calculated.

The Primary SPs are:

- Mean Drop, " $D_{m}$ "; It is the mean value of the Bid Drops submitted by the total number of bidders admitted in a particular tender contest. The relation with the Mean Bid $\left(\mathrm{B}_{\mathrm{m}}\right)$ in monetary value is: $B_{m}=\left(1-D_{m}\right) A$.

- Maximum Drop, " $D_{\max }$ "; it is the per-unit Drop corresponding to the Lowest Bid submitted by the bidders. Its relation with the Minimum Bid $\left(B_{\min }\right)$ in monetary value is: $B_{\min }=\left(1-D_{\max }\right) A$.

- Minimum Drop, " $\mathrm{D}_{\min }$ "; it is the per-unit Drop corresponding to the Maximum Bid submitted by the bidders. Its relation with the Maximum Bid $\left(B_{\max }\right)$ in monetary value is: $B_{\max }=\left(1-D_{\min }\right) A$.

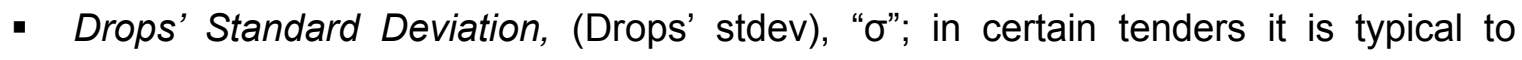
express Abnormally Low Bids Criteria (ALBC) on a percent or multiple basis relative to the Standard deviation values of the bids. Its relation with Bids' Standard Deviation (S) (Bids' stdev) in monetary value is: $S=\sigma \cdot A$.

The second group of SPs consists of the Secondary SP. As mentioned above, they result from the calculation of one or more primary SPs. For simplicity, only the main Secondary SP used in the upcoming model is described:

- Abnormal Drop " $\mathrm{D}_{\text {abn" }}$ is the Drop Threshold value; bids below this threshold value will be considered abnormal or risky. The Abnormal Drop is calculated through a formula that includes some primary SPs such as $D_{m}$ (for example, a certain percentage value lower than the Mean Drop). Its relation with Abnormal Bid $\left(B_{a b n}\right)$ in monetary value is $B_{a b n}=\left(1-D_{a b n}\right) A$. When $D_{a b n}$ is calculated as a relative distance $T$ (in per-unit values) from $D_{m}$, the expression is $D_{a b n}=1-(1-T)\left(1-D_{m}\right)$ and when it is calculated as a constant distance $T$ from $D_{m}$, the expression is $D_{a b n}=D_{m}+T$. 
Primary and Secondary SPs are combined mathematically to generate specific ESFs for each specific tender and should be clearly specified in the tender specifications and contract conditions by the employer.

Additionally, a third group of variables includes:

"Forecasting Parameter"(FP). FP refers to the variables that can be known in advance before the deadline of a tender. Their values must be closely related to the SPs to be useful. In this study the variable "Estimated Cost" $\left(D_{0}\right)$ is used as a FP calculated in per-unit Drop rather than in monetary value.

Although some other variables, such as GDP, have been used in other models to make predictions they have always shown weaker connections with the SPs used in the forthcoming model.

\section{Fieldwork}

A total of 120 real tender documents of Spanish Public Administrations and private companies were analyzed in order to obtain the Scoring Parameters (SPs) and Economic Scoring Formulas (ESFs) used in the comparison model.

The dataset collected and analyzed can be considered as representative of a public capped tender process as it comprises: Tender contests and Auctions, all kinds of public administrations (city councils, local councils, semi-public entities, universities, ministries, and so on), a great variety of civil engineering works and services, representation of different geographical regions (including the islands) and a wide range of Tender Amounts. Although the sample only contains Spanish tender documents, the ESFs and SPs analyzed are applicable to any country where the Administration sets up an initial Tender Amount (A) against which candidates will underbid (capped tendering or upper-limited-price tendering).

The specification of an initial Amount $A$ in the tender document allows bidders to underbid the initial offer. The mathematical relationships presented in this paper work well with both Tender Amounts $(A)$ and Bid Drops (discount given by a bidder to a Tender Amount). The examples presented here have been calculated using Bid Drops expressed in per-unit values.

Among the wide range of tender documents collected (see Ballesteros-Pérez, 2010, Annex I), several Public Administrations generated a large enough number of tendering processes to permit an in-depth statistical analysis. Although the results obtained from those Public Administrations were invariably very similar, a sub-dataset from a particular Public Administration (see Ballesteros-Pérez, 2010, Annex II) was selected in order to illustrate the 
mathematical relationships between the SPs and one FP (Estimated Cost or $D_{0}$, in this case) through a numerical example.

The selected Public Administration is the "Agencia Catalana del Agua" (Catalonian Water Agency), ACA hereinafter, a semi-Public Administration which manages most of the water supply system in the four Spanish Catalonian provinces. ACA managed fifty-one construction tenders in approximate one year (from May 2007 to June 2008) and used the same ESFs in the tender specifications.

In order to avoid misleading results, tenders with less than three bidders were removed from ACA's dataset, leaving a total of forty-five tenders. (Table 1 in Appendix B shows ACA's dataset). Besides, taking into account that each dataset sets certain numerical values to some correlation coefficients (called $a, b$ and $c$ ), the purpose of representing only a subdataset is not to mix results from heterogeneous sources, that is, with different ESFs and SPs.

To sum it up, the dataset analyzed was large enough to draw conclusions from countries in which a tender amount $A$ is pre-set by the employer, but only a little part of the aforementioned dataset has been shown here (mainly in Tables 1 and 3), especially to allow representing homogeneous graphs with sufficient data points in them.

\section{Relationships between SPs}

Many studies in the literature are aimed at determining bidders' bidding behavior patterns. The classical approach in Bid Tender forecasting models is based on the aggregation of particular probabilistic behaviors of particular bidders in a major model that could predict which bidders are going to bid.

The main problems of these models are the large amounts of data belonging to individual bidders that have to be analyzed in order to find out which bidders would probably bid in forthcoming tenders, the big amount of data required to describe each bidder's behavior and the way of predicting which bidders will take part in forthcoming tender processes. Besides, there is a real difficulty in identifying how bidders' behavior changes in the course of tenders because even more data would be needed.

Since none of these problems has been successfully addressed yet, this paper proposes an alternative way of approaching the problem, namely to study bidders' behavior as a whole, that is, to study their descriptive parameters but as a group by means of Scoring Parameters, such as Mean Drop, Minimum Drop, Maximum Drop and so on. This approach enables obviating the "name" of the bidders that will take part in forthcoming auctions or 
tenders as well as using a substantially smaller dataset of previous tenders. In upcoming papers where the Bid Tender Forecasting Model (BTFM) will be explained in detail, it will also be shown how temporary changes in these parameters are significantly easier to detect and monitor than changes in a single bidders' behavior separately.

As the paper shows, though a complete study comprising a large number of different Public Administration tenders was conducted, for the sake of illustration only a sub-dataset from one particular Public Administration (ACA) is presented in the present paper.

The data shown in Table 1 (Appendix B) are represented in a graph where the $\mathrm{X}$-axis represents the values of the SP mean Drop $\left(D_{m}\right)$ and the $Y$-axis represents the $D_{\max }$ 's, $D_{\min }$ 's, $\sigma$ 's and $D_{m}$ 's (again) actual values of each tendering process. That means that each $X$ value represents a single tender in which each $Y$ value is given by the real $S P s\left(D_{\max }, D_{m}, D_{\min }\right.$, and $\sigma$ ) which led to that tender after the bids (in this case converted to Drops in per-unit values) were known, i.e., after the bids were opened.

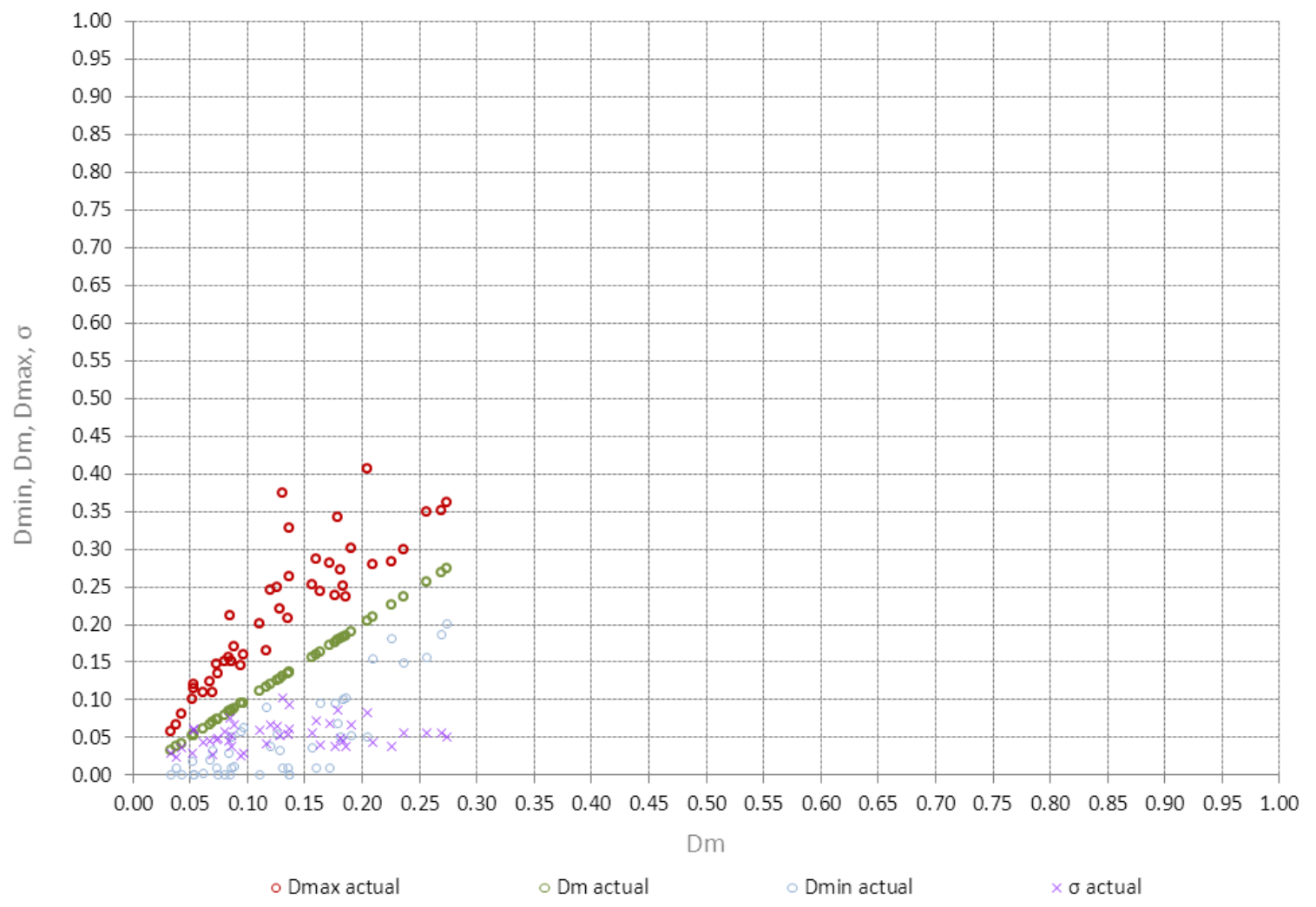

Figure 1: Representation of actual values of SPs from Table 1 (Appendix $B$ ): $D_{\min }$. $D_{\max }$ and $\sigma$ from previous ACA's Tenders

Different mathematical expressions were tested for the regression analysis, two groups of which were, by far, the best correlated: 


\section{a) Potential expressions}

$D_{\text {max }}=D_{m}{ }^{a} ; D_{\text {min }}=D_{m}{ }^{b} ; \sigma=c\left(D_{\max }-D_{\min }\right)$

b) Parabolic expressions

$$
D_{\max }=a D_{m}^{2}+(1-a) D_{m} ; D_{\min }=b D_{m}^{2}+(1-b) D_{m} ; \sigma=c\left(D_{m}^{1 / 3}-D_{m}\right)
$$

The regression expressions of $D_{\max }$ and $D_{\min }$ are curves that cross the points $(X, Y)=\left(D_{m}\right.$, $D_{\max }$ or $\left.D_{\min }\right)=(0,0)$ and $(1,1)$. This happens due to two basic mathematical assumptions that correspond to boundary conditions:

1. When the Mean Drop is zero, that is, none of the bidders have underbid the Tender Amount $A ; D_{\min }$ cannot be negative (because overbidding $A$ is usually forbidden when a Tender Amount has been preset) so it has to be zero too; then $D_{\max }$ cannot have a value other than zero, otherwise, $D_{m}$ could not be zero. This fact finally means that the three regression curves must coincide at point $(0,0)$.

2. When the Mean Drop is 1 (an extreme condition in which all the bidders have submitted a completely free bid), $D_{\max }$ cannot be higher than 1 (because "any Drop equals 1" means offering a zero price, that is, the price offered is completely free); then $D_{\text {min }}$ cannot have a value other than 1 , otherwise $D_{m}$ could not be 1 . Again, any regression curve represented in the selected $X$ and $Y$ axes, must coincide at point $(1,1)$.

On the other hand, the two expressions of $\sigma$ must be a curve that passes through the following points: $(X, Y)=\left(D_{m}, \sigma\right)=(0,0)$ and $(1,0)$. In this case the explanation is easier, in these two points $D_{m}=D_{\min }=D_{\max }$, there is no dispersion in Drops and, therefore, there cannot be any $\sigma$-value different from zero.

However each group of equations has pros and cons:

a) Potential expressions show the best Correlation factors but the differences between estimated and actual data do not respond to any known Probability Density Function.

b) Parabolic expressions have Correlation factors almost as high as Potential expressions but they do generate a Normal Distribution between estimated and actual data (only known after the tenders' results are published with a detailed list of bidders' bids), which will lead to a considerably easier and less complex BTFM mathematical body. 
Of course, there are many other mathematical expressions that can somehow improve correlation, but all of them require fitting more than one variable. By contrast, the two groups of expressions mentioned above have the great advantage of using only one variable $(a, b$ and $c$ respectively to $D_{\max }, D_{\min }$ and $\sigma$ ), which greatly simplifies the calculation process not avoiding linear approximations as well.

Hence, it is recommended to use potential expressions when there are very few previous tenders, for instance, less than 3 , and parabolic expressions for historical data with more than 2 tenders. Therefore, as a general rule, parabolic expressions are preferred in BTFM models when the final number of bidders is unknown.

\subsection{Calculation of the coefficients and their Correlation factors}

To fit the parabolic curves shown in the previous section in any dataset, it is necessary to calculate the values of coefficients $a, b$ and $c$ from equations 5,6 and 7 . These coefficients were calculated as follows for the ACA's sub-dataset.

Given the data from a tender " $k$ " (bidder's bids must be known), that is, given the values of $D_{m ~ k}, D_{\operatorname{max~k}}, D_{\min k}$ and $\sigma_{k}$, the coefficients $a, b$ and $c$ can be easily calculated with the following expressions:

$$
a_{k}=\frac{D_{\max k}-D_{m k}}{D_{m k}{ }^{2}-D_{m k}} ; \quad b_{k}=\frac{D_{\min k}-D_{m k}}{D_{m k}{ }^{2}-D_{m k}} ; c_{k}=\frac{\sigma_{k}}{D_{m}^{1 / 3}-D_{m}}
$$

Once these coefficients ( $a, b$ and $c$ ) were obtained for all available previous tenders, their average and standard deviation values were calculated (Table 1, Appendix B).

The coefficient values calculated by means of equations 8,9 and 10 (Table 1, Appendix B) were used to generate Table 2 (Appendix B) and Figure 2. 


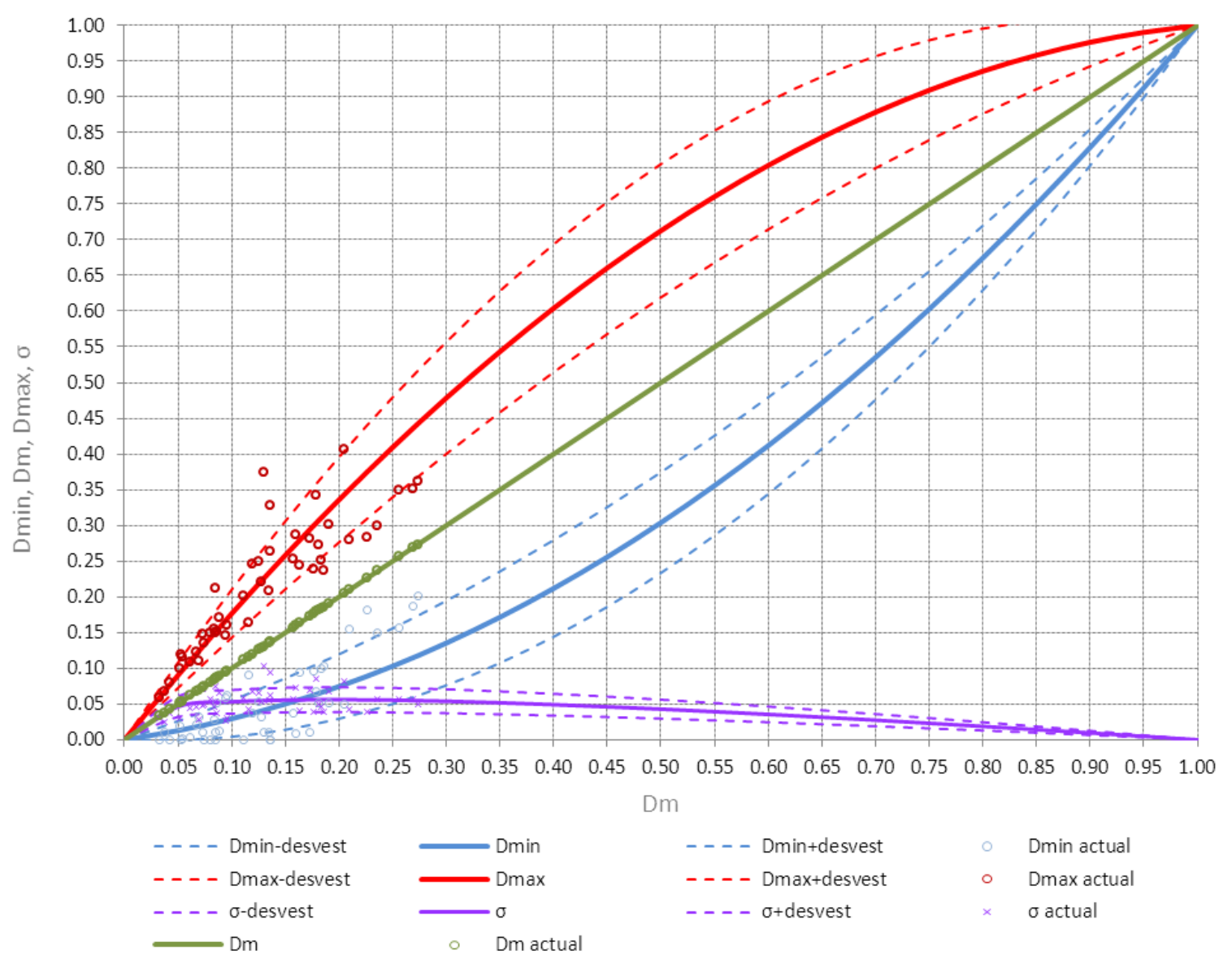

Figure 2: Representation of actual values from Table 1 (Appendix B) and Parabolic Regression Curves of $D_{\min }, D_{\max }$ and $\sigma$.

In the previous figure it can be observed that the parabolic curves fit actual data (the $D_{\max }$, $D_{\min }, D_{m}$ and $\sigma$ values that really happened) fairly well, however, to assign numerical values, correlation factors $\left(R\right.$ and $R^{2}$ ) were calculated for each kind of curve $\left(D_{\min }, D_{\max }\right.$ and $\sigma$ ) (Table 3, Appendix B). Summarizing, the correlation factors of $D_{\max }$ and $D_{\min }$ are about $90 \%$, but $\sigma$-curves can be further improved $(R=43 \%)$. It must be taken into account that the tender sub-dataset used includes different construction works, and this fact introduces a certain degree of heterogeneity in the values.

A final SP worth mentioning is $D_{a b n}$, which is a Secondary Scoring Parameter. This SP can be calculated in different ways depending on the tender conditions. The more usual way of calculating this parameter is through an expression directly related to $D_{m}$, for example $\mathrm{D}_{\mathrm{abn}}=1-(1-\mathrm{T})\left(1-\mathrm{D}_{\mathrm{m}}\right)$ or $\mathrm{D}_{\mathrm{abn}}=\mathrm{D}_{\mathrm{m}}+\mathrm{T}$, where $\mathrm{T}$ is called "Abnormally High Drop Threshold" and is a numerical value usually set by the Public Administration in the case of Spain within a range of values between 0.05 and $0.20(0.10$ is the value set up in the Spanish Public Procurement Law). 
Since $D_{a b n}$ is directly obtained from any given value of the SP $D_{m}$ there is no need to search for regression curves, and, obviously, there will be no deviations between actual and estimated data.

\subsection{Checking Normality assumption of variation}

An important advantage of parabolic curves is that they allow the study of the deviations between estimated and actual values of $D_{\max }$ and $D_{\min }$, as if they were distributed according to a Normal Distribution Function.

To check this assumption and taking into account that each homogeneous sample rarely contains more than fifty values (not only this sub-dataset but every dataset from most employers' tenders before they introduce a change in their ESFs), two Shapiro-Wilk tests (Shapiro \& Wilk, 1965) were used to check for normality between estimated and actual data for the expressions of $D_{\max }$ and $D_{\min }$. (both in our sub-dataset and the rest of tenders analyzed in Spain).

Whereas the Shapiro-Wilk test for $D_{\max }$ accomplishes the condition of exceeding the statistical test parameter $W_{\text {tab }}$ for $\alpha=5 \%, D_{\min }$ is on the edge. This is due to the fact that $D_{\min }-$ values have an under-limitation, that is, $D_{\min }$ values can never be negative so there is a constraint that affects the Normality assumption. However, it has been verified that in tenders where bidders can bid over the initial Tender Amount (where $D_{\text {min }}$-values can be negative) the Normal Distribution assumption is fulfilled. Moreover, if $D_{\min }$ 's extreme values were not taken into account, Shapiro-Wilk tests would be fulfilled as well.

The procedure used to solve this problem was very simple: the Normal distribution of $D_{\text {min }}$ curves is accepted until they reach zero-values, then, the rest of the probability's tail of the Normal Distribution Function is assigned to "Drops $=0$ ".

Finally, whereas the $D_{\max }$ and $D_{\min }$ curves cross the clouds of actual Tenders' $D_{\max }$ and $D_{\min }$ values generating Normal Distribution data on both sides of the average curves, this does not happen in the $\sigma$-curves. None of the Shapiro-Wilk tests used so far in a wide variety of mathematical expressions has ever fulfilled this condition, nor have they ever shown a high enough Correlation factor.

Since SP $\sigma$ is not as important as SPs $D_{\max }$ and $D_{\min }$, ongoing research is currently checking different tentative mathematical expressions for the forthcoming BTFM model, like the expression shown in equation 7 . 


\section{Relationships between SPs and FPs}

For the design of a Bid Tender Forecasting Model (BTFM) it is necessary to correlate the variables used in the model. Basically there are two kinds of variables: Scoring Parameters (SP) and Forecasting Parameters (FP).

SPs were described above so that their range of values can be estimated provided the values of at least one SP were. This can be considered a kind of forensic analysis in the sense that the values of the SPs can be known once the tender has finished, but not before. To predict the values of these SPs new variables, called "Forecasting Parameters", will have to be used.

"Forecasting Parameters" (FP) are variables that can be known before the deadline of the tender offering is reached and that show the relationship with the SPs. Therefore, to estimate the value of a FP it will suffice to know which competitors' Bids can be statistically expected (through SP Forecasting). Of course, the identification of good FPs is the most difficult issue in a BTFM.

Some recent conceptual models have been developed for use by contractors as part of a more reliable approach to identify key competitors and as a basis for formulating bidding strategies (Oo et al., 2008a, 2010). Competitiveness between bids is examined with linear mixed models that use variables such as project type and size, work sector; work nature; market conditions and number of bidders (Oo, et al., 2008a, 2008b). Some of these variables can be considered FPs (project type and size, work sector; work nature; market conditions) but they are difficult to quantify.

In this work, in an effort to keep the BTFM as simple as possible, "Estimated Cost" $\left(\mathrm{B}_{0}\right)$ has been chosen as the best possible FP. This monetary value is converted into a Drop-value, called $D_{0}$, by means of the expression $B_{0}=\left(1-D_{0}\right) A$, that is, a linear expression but only when the SPs and FP are expressed in Drops (never in monetary values).

$D_{0}$ is the Drop below which one bidder makes profit (offering a lower Drop value means offering a bigger amount of money with a higher mark-up for the bidder) and above which the bidder loses money (offering a higher Drop value means offering a smaller amount of money to increase the chances of winning a tender).

There are techniques to forecast tight prices for a particular construction work or a singular project based on the experience of an organization, its resources and available personnel, inflation rates since the last time a similar action was performed, the situation of the 
contracting Administration and even on the situation of the country which receives the tender's action (Thomas, et al., 2004). Recently several studies which combine statistical regression analysis with Temporary Series have been conducted. Temporary series allow bidders to estimate with certain degree of accuracy how much it will cost to execute a particular work or project (Thomas, et al., 2004).

Consulting and Construction companies need to control their cost in order to obtain benefits when they accept a contract (Naoum, 1994). There are several methodologies to monitor and estimate costs:

- Initial approaches were based on subjective correlations between the elements and composition of the Construction Works (Touran, 1993) (for example, between the volume of Civil Works, Electromechanical equipment and Electrical Equipment) to estimate cost by means of inaccurate correlations that require relatively few calculations.

- Several methodologies are related to the features of the work to be done (Lowe et al., 2006)

- Other methodologies are based on the volume (Remer \& Buchanan, 2000) and time (Pellicer, 2005) of resources involved.

- Some models combine the two previous concepts through indices (Chang, 2001)

- More recently, logarithmic regression techniques combined with fuzzy variables have been developed as well (Hong, 2004). They are also applied to recommend a markup obviating the possible mark-ups from other competitors (Fayek, 1998).

- Other models have been developed to predict costs in the early stages of project execution once a company has been awarded a contract (Trost \& Oberlender, 2003)

- The latest approaches focus on the design of models that scale cost estimates with a view to bid with higher accuracy according to the real market situation (Oo et al., 2008a), taking into account the current situation of the proposing company (Touran \& Lopez, 2006) and the economic volume of the tender (Drew \& Skitmore, 1997).

The list presented above does not attempt to be comprehensive but to serve as an illustration. 
With respect to variable $D_{0}$, the only aspect significant enough is that this variable must always be calculated in the same way, which means:

- Being calculated by the same person or the same group of people using the same criteria.

- Aggregating the same type of costs every time (taxes, indirect costs, structure cost from the company, and so on). If some of these costs are neglected or left out, it is recommended to keep the same criteria while calculating forthcoming $D_{0}$-values.

- If a desired level of profit is included in $D_{0}$, the following times $D_{0}$ is calculated it must include the same profit's percentage.

- The type of works and the ESF must be the same in every case. When these items experience an important change, the historical data of $D_{0}$ will be deleted and it will be necessary to start from scratch correlating $D_{0}$ with the SPs for future tenders.

In other words, both accuracy and homogeneity while estimating cost are important, even if this cost is different for each company.

Next section describes the statistical relationship between $\mathrm{D}_{0}$ and the SPs presented before. In table 1 (Appendix $B$ ) some $D_{0}$-values are shown. These values were taken from a company which bided for 14 out of the 45 tenders in the list.

\subsection{Calculation of the coefficient and Correlation factor}

The proposed mathematical expression is a line which crosses point $(X, Y)=\left(D_{m}, D_{0}\right)=(1,1)$ and the equation is:

$$
D_{0}=1+d\left(D_{m}-1\right)
$$

Where coefficient " $d$ " is calculated in a given tender " $k$ " as:

$$
d_{k}=\frac{D_{0 k}-1}{D_{m k}-1}
$$

That is, working out the value of " $d$ " in equation 11 .

The equation proposed crosses point $(1,1)$ because whenever an estimated cost is equal to zero, the Mean Bid $\left(D_{m}\right)$ will be relatively very close to zero as well. In other words, if it happened that a tender had an extremely low estimated cost (Drop close to 1 ) the margin for profits every bidder would decide to include in their respective bid (since the margin for profit 
is a relative variable not an absolute variable) would have to decrease as long as the contract price approaches zero. At point $(1,1)$ the estimated cost of a tender would be completely free, which would mean that even applying a high percentage of profit to the bid, the bid would continue being free (Drop equals 1) and, finally, the average of bidders' bids (Mean Bid, $D_{m}$ ) would be 1 again.

This assumption simplifies again the equation from two variables to only a single variable, " $d$ ".

The values of $d_{k}$ are shown on the right column of Table 1 (Appendix $B$ ); the regression curves of $D_{0}$ are listed in the three right columns of Table 2 (Appendix $B$ ), and the estimated values of $D_{0}$ and correlation factors between $D_{0}$ and $D_{m}$ are shown in Table 3 (Appendix $B$ ).

Figure 3 shows the plot of the average $D_{0}$-curve plus its two confidence intervals of standard deviation.

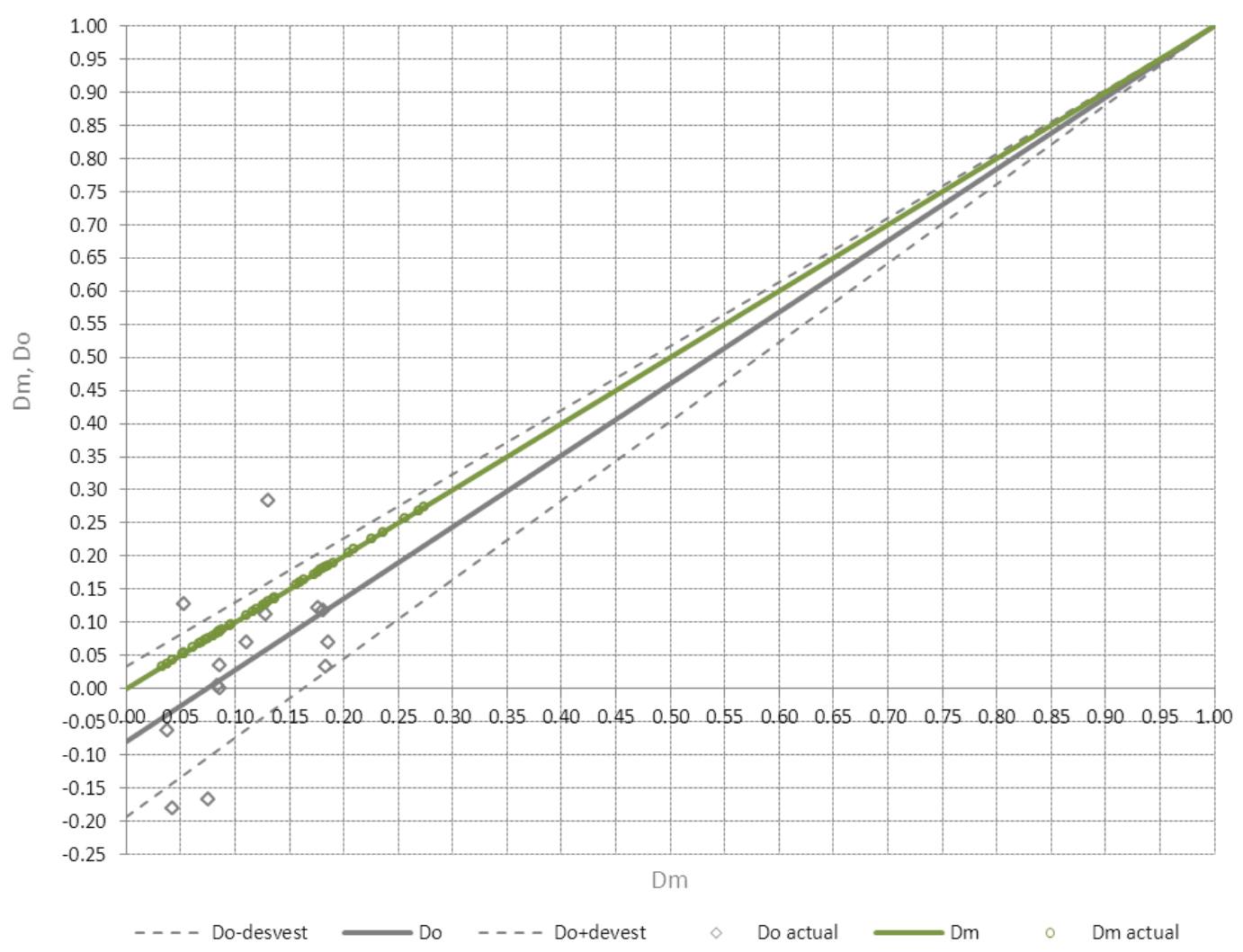

Figure 3: Representation of actual values from Table 1 (Appendix B) and Linear Regression Curves of $D_{0}$.

The Correlation factor this time is equal to $54 \%$. It might not be considered a particularly high value, but it must be taken into account that different kinds of construction works are involved, for example, if Tender with ID \#10 is removed (because it involves only the 
construction of Sewer Systems, while the others involve the construction of either WWTPs or WWTPs plus Sewer Systems) the correlation factor rises up to $60 \%$. In many other studies carried out by the authors, the correlation factor rises up to $90 \%$ when the determination of estimated costs is very narrow (for example, in some Exploitation and Maintenance Services).

\subsection{Checking Normality assumption of variation}

Even considering correlation factors around $54 \%$, again this mathematical relationship has the advantage that deviations between $D_{0}$ and $D_{m}$ actual values follow a Normal Probability Distribution Function (but remember again that this only happens when the parameters are expressed in Drops not in monetary values), which enables easily integrating this mathematical expression in a future BTFM.

Another Shapiro-Wilk (Shapiro \& Wilk, 1965) test was applied to the estimated $D_{0}$ and actual $D_{m}$ values. As $W_{c a l}$-value exceeded $W_{\text {tab }}$ value with $\alpha=5 \%$, so Normal distribution between these two variables is acceptable.

In Figure 4 the dispersion of $D_{m}$ data is represented in a graph where the $X$-axis represents $\mathrm{D}_{0}$-values.

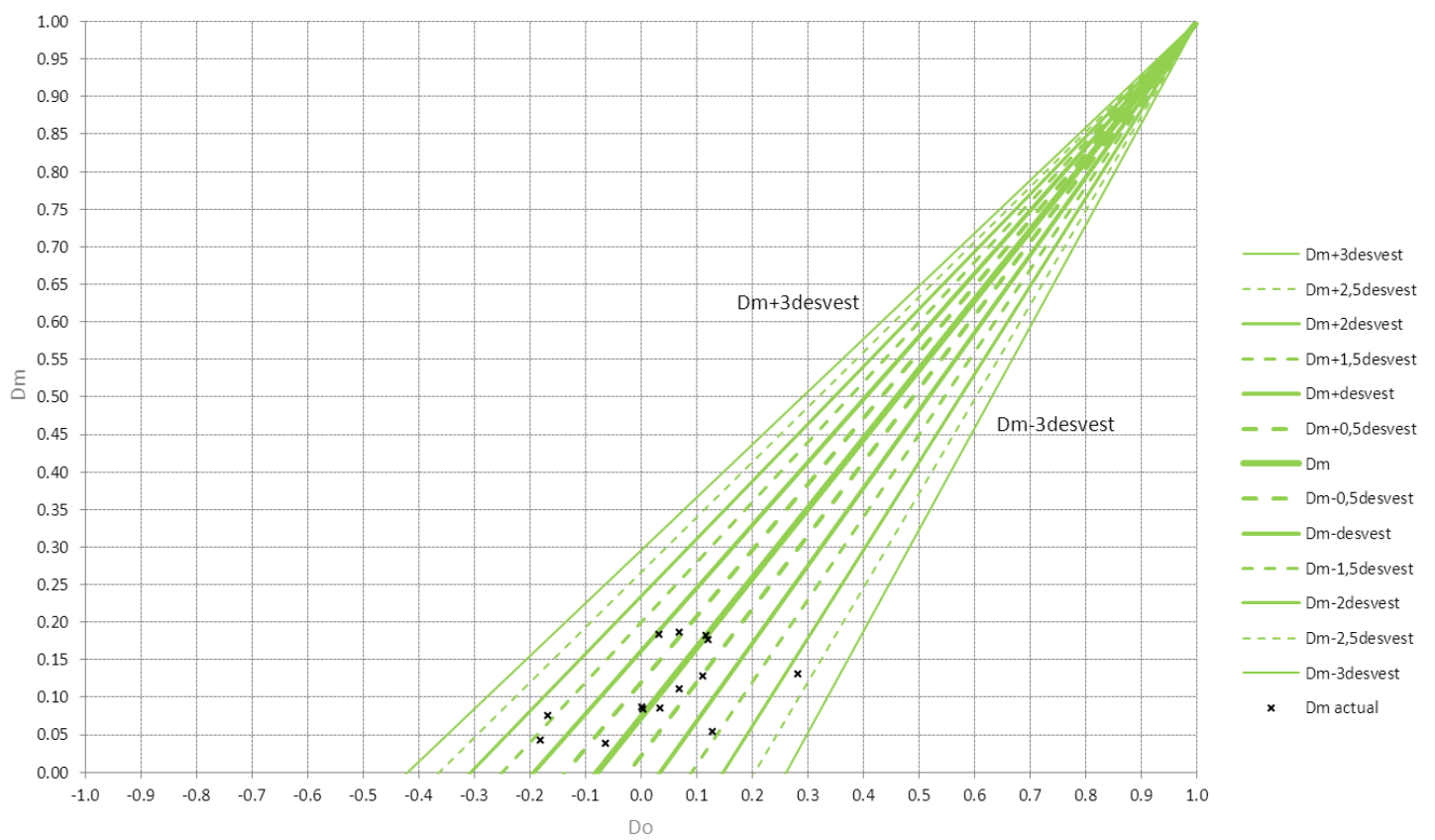

Figure 4: Representation of actual $D_{m}$-values' dispersion.

Once the relationship between $D_{0}$ and $D_{m}$ has been identified, $D_{0}$ can be mathematically correlated to any of the other SPs, that is the BTFM's basis. 


\section{Conclusions and Discussion}

Several mathematical and statistical relationships between Scoring Parameters, particularly Primary Scoring Parameters, have been described in this paper when expressed in Drop values. Subsequently, a Forecasting Parameter was introduced and its relationship with the SPs was determined.

The obtained Correlation Coefficients were reasonably high in almost every relationship except for the tentative relationship between $\sigma$ and $D_{m}$.

The Probability Distribution Functions obtained were Normal Distribution Functions in most cases when parabolic and linear functions are used to determine the relationships between Scoring and Forecasting Parameters respectively.

The relative simplicity of the mathematical expressions proposed in this work with only one coefficient to be determined in each relationship, the simple calculation procedure used to estimate these coefficients and variables, and the description of SPs' variation through a standard distribution function allow fitting regression curves and density distribution functions to any new tender dataset using basic, simple and direct calculations, even in cases with few previous historical data.

Other mathematical expressions will be used in the future to improve the obtained correlation coefficient values in this study, although the relationships shown in this paper are accurate enough to be used in a general Bid Tender Forecasting Model with a relatively basic background in tendering and statistical analysis.

Nevertheless, the BTFM that will be presented will not be universal, since it will be based on the expressions shown in this paper that have only been applied to capped tendering.

Many countries use capped tendering procedures when they publish their contracts to potential contractors. This is the case of Spain, but there are a large number of other countries which use both capped and non-capped tenders depending on either the kind of contract or the existence of a previous project which estimates an initial monetary amount.

However, the results obtained in this paper are equally applicable to any country that uses capped tendering, because the parameters will be exactly the same only differing in their specific numerical values in each type of contract with a particular Economic Scoring Formula and economic environment. Nonetheless, non-capped tendering is most common in many countries so the expressions stated above will have to be finally adapted.

Fortunately, the different variables of the model can be transformed to be set as a function of monetary values instead of drop values, which is indispensable in non-capped tendering. The next aim is to transform the main mathematical relationships between Scoring 
Parameters so that they can work without a pre-set tender amount against which the bidders can only underbid.

Whereas capped tendering can use drops (X-axis values ranging from 0 to 1$)$, non-capped tendering will have to use semi-infinite ranges of values on the $X$-axis (prices ranging from 0 to infinite). Moreover, both capped and non-capped tendering will share some boundary conditions regarding SPs, therefore, the adaption can be researched.

Once the expressions are generated for non-capped tendering, every possible contract will be able to be forecast without further problems.

\section{Future work}

The statistical relationships described in this paper correspond to the second part of a larger Bid Tender Forecasting Model (BTFM). While the first part consisted of the development of the iso-Score Curves Graph (iSCG) (Ballesteros-Pérez, et. al, 2011), in the third part, based on the relationships and parameters presented in this paper the iso-Score Curves will be used again to generate two types of new graphs very useful to make predictions: (1) the Scoring Probability Graph and (2) the Position Probability Graph.

Given any capped tender specifications and for every possible Drop (or monetary value) the Scoring Probability Graph will represent the probabilities of exceeding every economic score.

The Position Probability Graph will state the chances of occupying every possible position for every Drop or monetary bid proposed by any potential bidder, given several probabilistic values about the number of bidders who will take part in a tender.

The complete BTFM will be useful for both bidders and contractors to predict different bidding scenarios based on capped tender specifications.

\section{Appendix A}

Main abbreviations used in the text:

A Amount of money of a Tender (price's upper limitation)

a regression coefficient to adjust the relationship between $D_{\max }$ and $D_{m}$

ALB Abnormally Low Bid

ALBC Abnormally Low Bid Criteria

B Bid (expressed in monetary value)

b regression coefficient to adjust the relationship between $D_{\min }$ and $D_{m}$ 
$\mathrm{B}_{\mathrm{i}} \quad$ Bidder $\mathrm{i}$ Bid (expressed in monetary value)

$\mathrm{B}_{\mathrm{m}} \quad$ Mean Bid (expressed in monetary value)

$\mathrm{B}_{\max }$ Highest Bid (expressed in monetary value)

$B_{\min } \quad$ Lowest Bid (expressed in monetary value)

BTFM Bid Tender Forecasting Model

c regression coefficient to adjust the relationship between either $\sigma$ and $D_{m}$ (in the case of parabolic curves) or between $\sigma$ and $D_{\max }$ and $D_{\min }$ (in the case of potential curves)

D Drop (expressed in per-unit value)

$D_{\text {abn }} \quad$ Abnormal Drop

$D_{i} \quad$ Bidder $i$ Drop (expressed in per-unit value)

$D_{m} \quad$ Mean Drop (expressed in per-unit value)

$D_{\max } \quad$ Maximum Drop (expressed in per-unit value)

$D_{\min } \quad$ Minimum Drop (expressed in per-unit value)

ESF Economic Scoring Formula

iSC iso-Score Curve

iSCG iso-Score Curve Graph

S Bids' Standard Deviation (expressed in monetary value)

$\mathrm{S}_{\mathrm{i}} \quad$ Score of Bidder $i$ (expressed either in points or in per-unit value)

SP Scoring Parameter

T Abnormally High Drop Threshold

WWTPWaste Water Treatment Plant

$\sigma \quad$ Drops' Standard Deviation (expressed in per-unit value) 


\section{Appendix B}

\begin{tabular}{|c|c|c|c|c|c|c|c|c|c|c|c|c|c|c|c|}
\hline $\begin{array}{l}\text { Tender } \\
\text { Code }\end{array}$ & ID & Tender Deadline & $\begin{array}{l}\text { EPW } \\
\left({ }^{*} 1\right)\end{array}$ & $\begin{array}{l}\text { Nature of } \\
\text { Work (*2) }\end{array}$ & $\begin{array}{c}\text { Tender } \\
\text { Amount (€) }\end{array}$ & $\mathbf{N}$ & Dmin & Dm & Dmax & $\boldsymbol{\sigma}$ & Do & $\begin{array}{c}a \\
\text { (Dmax) }\end{array}$ & $\begin{array}{c}\text { b } \\
\text { (Dmin) }\end{array}$ & $\begin{array}{c}c \\
(\sigma)\end{array}$ & $\begin{array}{l}\mathrm{d} \\
(\mathrm{Do})\end{array}$ \\
\hline СТ08001116 & 1 & 2008-06-16 & 0.40 & WWTP+SW & $6,131,465.05 €$ & 13 & 0.0000 & 0.1111 & 0.2013 & 0.0589 & 0.0700 & -0.9133 & 1.1250 & 0.1594 & 1.0463 \\
\hline СТ07002839 & 2 & $2008-05-20$ & 0.40 & WWTP & $819,065.86 €$ & 4 & 0.0010 & 0.0536 & 0.1149 & 0.0591 & 0.1280 & -1.2077 & 1.0369 & 0.1826 & 0.9214 \\
\hline СТ08000938 & 3 & $2008-05-20$ & 0.40 & sW & $310,330.37 €$ & 14 & 0.0100 & 0.0735 & 0.1476 & 0.0477 & & -1.0870 & 0.9325 & 0.1381 & \\
\hline СТ08000941 & 4 & $2008-05-20$ & 0.40 & ELEC & $138,782.77 €$ & 3 & 0.0902 & 0.1162 & 0.1643 & 0.0417 & & -0.4686 & 0.2535 & 0.1122 & \\
\hline СТ07002792 & 5 & $2008-05-08$ & 0.40 & WWTP & $1,170,445.54 €$ & 11 & 0.0000 & 0.0748 & 0.1353 & 0.0493 & -0.1670 & -0.8735 & 1.0809 & 0.1423 & 1.2614 \\
\hline СТ08000553 & 6 & $2008-04-28$ & 0.40 & WWTP+SW & $744,935.13 €$ & 5 & 0.0000 & 0.0421 & 0.0803 & 0.0369 & -0.1800 & -0.9473 & 1.0439 & 0.1208 & 1.2318 \\
\hline СТ08000597 & 7 & $2008-04-28$ & 0.40 & WWTP & $966,499.89 €$ & 6 & 0.0515 & 0.0862 & 0.1515 & 0.0379 & 0.0010 & -0.8280 & 0.4403 & 0.1067 & 1.0933 \\
\hline СТ08000389 & 8 & 2008-03-31 & 0.40 & WWTP & $4,745,844.66 €$ & 22 & 0.0514 & 0.1813 & 0.2732 & 0.0491 & 0.1170 & -0.6193 & 0.8751 & 0.1277 & 1.0786 \\
\hline СТ07003248 & 9 & $2008-03-25$ & 0.40 & WWTP+SW & $3,347,952.13 €$ & 10 & 0.0000 & 0.0799 & 0.1501 & 0.0572 & & -0.9548 & 1.0868 & 0.1630 & \\
\hline СТ08000257 & 10 & 2008-03-19 & 0.40 & sw & $1,320,041.06 €$ & 25 & 0.1002 & 0.1835 & 0.2508 & 0.0457 & 0.0330 & -0.4489 & 0.5560 & 0.1188 & 1.1843 \\
\hline СТ08000137 & 11 & 2008-03-05 & 0.40 & sw & $262,217.31 €$ & 11 & 0.0539 & 0.1257 & 0.2500 & 0.0647 & & -1.1308 & 0.6533 & 0.1725 & \\
\hline СТ07003152 & 12 & $2008-02-11$ & 0.40 & SW & $7,096,107.23 €$ & 43 & 0.0092 & 0.1601 & 0.2860 & 0.0729 & & -0.9357 & 1.1223 & 0.1903 & \\
\hline СТ07003153 & 13 & $2008-02-11$ & 0.40 & SW & $8,229,123.67 €$ & 43 & 0.0517 & 0.1901 & 0.3009 & 0.0672 & & -0.7198 & 0.8989 & 0.1745 & \\
\hline СТ07002641 & 14 & $2008-01-28$ & 0.40 & WWTP & $20,368,617.61 €$ & 12 & 0.1861 & 0.2687 & 0.3505 & 0.0569 & & -0.4160 & 0.4205 & 0.1510 & \\
\hline СТ07002800 & 15 & $2008-01-28$ & 0.40 & SW & $24,811,128.46 €$ & 23 & 0.2015 & 0.2734 & 0.3610 & 0.0500 & & -0.4410 & 0.3619 & 0.1330 & \\
\hline СТ07002802 & 16 & $2008-01-28$ & 0.40 & SW & $11,588,648.39 €$ & 39 & 0.1571 & 0.2557 & 0.3500 & 0.0559 & & -0.4956 & 0.5180 & 0.1476 & \\
\hline Ст07003157 & 17 & $2008-01-28$ & 0.40 & sw & $432,624.04 €$ & 18 & 0.0370 & 0.1569 & 0.2525 & 0.0566 & & -0.7234 & 0.9063 & 0.1480 & \\
\hline СТ07002822 & 18 & $2008-01-23$ & 0.40 & WWTP & $2,279,367.16 €$ & 14 & 0.1028 & 0.1854 & 0.2367 & 0.0381 & 0.0700 & -0.3398 & 0.5470 & 0.0991 & 1.1416 \\
\hline СТ07002921 & 19 & $2008-01-23$ & 0.40 & WWTP & $4,346,995.62 €$ & 6 & 0.1818 & 0.2262 & 0.2833 & 0.0383 & & -0.3268 & 0.2533 & 0.1001 & \\
\hline СТ07002648 & 20 & $2007-12-31$ & 0.40 & sw & $7,018,943.29 €$ & 45 & 0.0003 & 0.1362 & 0.3282 & 0.0935 & & -1.6310 & 1.1552 & 0.2470 & \\
\hline СТ07002660 & 21 & $2007-12-31$ & 0.40 & WWTP+SW & $1,404,221.70 €$ & 7 & 0.0290 & 0.0839 & 0.1555 & 0.0453 & 0.0040 & -0.9306 & 0.7144 & 0.1279 & 1.0872 \\
\hline СТ07002721 & 22 & $2007-12-31$ & 0.40 & SW & $1,524,669.38 €$ & 19 & 0.0950 & 0.1632 & 0.2436 & 0.0398 & & -0.5885 & 0.4995 & 0.1038 & \\
\hline СТ07002733 & 23 & $2007-12-31$ & 0.40 & WWTP & $1,309,246.31 €$ & 4 & 0.0100 & 0.0374 & 0.0675 & 0.0239 & -0.0630 & -0.8349 & 0.7614 & 0.0805 & 1.1043 \\
\hline СТ07002108 & 24 & $2007-12-11$ & 0.40 & WWTP & $5,208,624.36 €$ & 22 & 0.0955 & 0.1765 & 0.2390 & 0.0386 & 0.1210 & -0.4301 & 0.5573 & 0.1003 & 1.0674 \\
\hline
\end{tabular}




\begin{tabular}{|c|c|c|c|c|c|c|c|c|c|c|c|c|c|c|c|}
\hline СТ07002493 & 25 & $2007-12-11$ & 0.40 & sW & $2,739,723.18 €$ & 25 & 0.0500 & 0.2043 & 0.4062 & 0.0821 & & -1.2413 & 0.9493 & 0.2134 & \\
\hline СТ07002568 & 26 & $2007-12-11$ & 0.40 & SW & $479,663.76 €$ & 9 & 0.0625 & 0.0961 & 0.1600 & 0.0300 & & -0.7359 & 0.3862 & 0.0829 & \\
\hline СТ07001934 & 27 & $2007-09-17$ & 0.40 & WWTP & $6,557,087.95 €$ & 16 & 0.0325 & 0.1277 & 0.2200 & 0.0530 & 0.1120 & -0.8282 & 0.8547 & 0.1409 & 1.0181 \\
\hline СТ07001972 & 28 & $2007-09-17$ & 0.40 & WWTP & $8,764,690.65 €$ & 10 & 0.1550 & 0.2097 & 0.2800 & 0.0428 & & -0.4246 & 0.3299 & 0.1112 & \\
\hline СТ07002052 & 29 & 2007-09-17 & 0.40 & WWTP & $6,217,700.13 €$ & 9 & 0.1489 & 0.2361 & 0.2985 & 0.0561 & & -0.3459 & 0.4837 & 0.1468 & \\
\hline СТ07001745 & 30 & $2007-08-31$ & 0.40 & SW & $8,834,150.00 €$ & 27 & 0.0103 & 0.1723 & 0.2818 & 0.0688 & & -0.7677 & 1.1359 & 0.1792 & \\
\hline СТ07001090 & 31 & $2007-08-30$ & 0.40 & WWTP & $1,043,243.40 €$ & 3 & 0.0000 & 0.0532 & 0.1200 & 0.0611 & & -1.3241 & 1.0562 & 0.1893 & \\
\hline СТ07001776 & 32 & $2007-08-30$ & 0.40 & WWTP+SW & $1,722,516.16 €$ & 6 & 0.0025 & 0.0613 & 0.1090 & 0.0441 & & -0.8289 & 1.0219 & 0.1324 & \\
\hline СТ07001903 & 33 & $2007-08-30$ & 0.40 & WWTP & $2,773,494.15 €$ & 9 & 0.0105 & 0.0855 & 0.1500 & 0.0523 & 0.0350 & -0.8248 & 0.9592 & 0.1474 & 1.0552 \\
\hline СТ07001957 & 34 & $2007-08-30$ & 0.40 & WWTP & $887,544.43 €$ & 9 & 0.0100 & 0.1307 & 0.3741 & 0.1028 & 0.2830 & -2.1436 & 1.0622 & 0.2729 & 0.8248 \\
\hline СТ07001003 & 35 & $2007-08-20$ & 0.40 & SW & $292,967.46 €$ & 5 & 0.0192 & 0.0519 & 0.1001 & 0.0297 & & -0.9811 & 0.6643 & 0.0925 & \\
\hline СТ07001602 & 36 & $2007-08-20$ & 0.40 & WWTP & $3,489,863.47 €$ & 9 & 0.0374 & 0.1199 & 0.2450 & 0.0666 & & -1.1863 & 0.7816 & 0.1785 & \\
\hline СТ07001042 & 37 & $2007-07-23$ & 0.40 & WWTP & $1,036,119.28 €$ & 3 & 0.0000 & 0.0327 & 0.0582 & 0.0298 & & -0.8044 & 1.0338 & 0.1037 & \\
\hline СТ06002801 & 38 & $2007-07-10$ & 0.40 & SW & $463,533.77 €$ & 12 & 0.0680 & 0.1792 & 0.3414 & 0.0860 & & -1.1032 & 0.7559 & 0.2237 & \\
\hline СТ07001376 & 39 & $2007-07-10$ & 0.40 & EW & $216,541.08 €$ & 5 & 0.0321 & 0.0699 & 0.1102 & 0.0277 & & -0.6202 & 0.5815 & 0.0809 & \\
\hline СТ07000948 & 40 & $2007-06-20$ & 0.40 & SW & $824,723.89 €$ & 12 & 0.0105 & 0.1348 & 0.2079 & 0.0548 & & -0.6272 & 1.0658 & 0.1450 & \\
\hline СТ07000957 & 41 & $2007-06-18$ & 0.40 & WWTP & $1,886,885.84 €$ & 8 & 0.0576 & 0.0947 & 0.1452 & 0.0256 & & -0.5885 & 0.4329 & 0.0708 & \\
\hline СТ07001150 & 42 & $2007-06-11$ & 0.40 & SW & $1,439,520.67 €$ & 20 & 0.0000 & 0.1363 & 0.2641 & 0.0621 & & -1.0852 & 1.1578 & 0.1642 & \\
\hline СТ07000938 & 43 & $2007-05-22$ & 0.40 & SW & $1,928,425.80 €$ & 11 & 0.0000 & 0.0849 & 0.2114 & 0.0749 & & -1.6276 & 1.0928 & 0.2112 & \\
\hline СТ07000944 & 44 & $2007-05-22$ & 0.40 & sW & $330,605.15 €$ & 4 & 0.0212 & 0.0676 & 0.1233 & 0.0457 & & -0.8840 & 0.7367 & 0.1345 & \\
\hline \multirow[t]{3}{*}{ СT07000884 } & 45 & $2007-05-17$ & 0.40 & SW & $2,866,122.06 €$ & 5 & 0.0121 & 0.0885 & 0.1700 & 0.0661 & & -1.0099 & 0.9471 & 0.1852 & \\
\hline & & & & & & & & & & & Average: & -0.8506 & 0.7842 & 0.1456 & 1.0797 \\
\hline & & & & & & & & & & & Desvest: & 0.3732 & 0.2820 & 0.0452 & 0.1135 \\
\hline
\end{tabular}

*1 EPW: Economic Proposal's (Bid) Weight in the tender

*2 WWTP (Construction of Waste Water Treatment Plant/s), SW (Construction of Sewerage System/s), EW (Earthworks) and ELEC (Electric Works).

Table 1: ACA's Tender Data and Calculations of parabolic expression parameters a, b, c and d 


\begin{tabular}{|c|c|c|c|c|c|c|c|c|c|c|c|c|}
\hline Dm & $\begin{array}{c}\text { Dmax } \\
\text { - desvest }\end{array}$ & Dmax & $\begin{aligned} & \text { Dmax } \\
+ & \text { desvest }\end{aligned}$ & $\begin{array}{c}\text { Dmin } \\
\text { - desvest }\end{array}$ & Dmin & $\begin{aligned} & \text { Dmin } \\
&+ \text { desvest }\end{aligned}$ & $\begin{array}{c}\sigma \\
\text { - desvest }\end{array}$ & $\sigma$ & $\begin{array}{c}\sigma+ \\
\text { desvest }\end{array}$ & $\begin{array}{c}\text { Do } \\
\text { - desvest }\end{array}$ & Do & $\begin{array}{c}\text { Do } \\
+ \text { devest }\end{array}$ \\
\hline Parameter: & -1.2237 & -0.8506 & -0.4774 & 0.5022 & 0.7842 & 1.0662 & 0.1004 & 0.1456 & 0.1908 & 0.9662 & 1.0797 & 1.1932 \\
\hline 0.0000 & 0.0000 & 0.0000 & 0.0000 & 0.0000 & 0.0000 & 0.0000 & 0.0000 & 0.0000 & 0.0000 & 0.0338 & -0.0797 & -0.1932 \\
\hline 0.0500 & 0.1081 & 0.0904 & 0.0727 & 0.0261 & 0.0127 & -0.0006 & 0.0320 & 0.0464 & 0.0608 & 0.0821 & -0.0257 & -0.1335 \\
\hline 0.1000 & 0.2101 & 0.1766 & 0.1430 & 0.0548 & 0.0294 & 0.0040 & 0.0366 & 0.0530 & 0.0695 & 0.1304 & 0.0283 & -0.0739 \\
\hline 0.1500 & 0.3060 & 0.2584 & 0.2109 & 0.0860 & 0.0500 & 0.0141 & 0.0383 & 0.0555 & 0.0728 & 0.1788 & 0.0823 & -0.0142 \\
\hline 0.2000 & 0.3958 & 0.3361 & 0.2764 & 0.1196 & 0.0745 & 0.0294 & 0.0386 & 0.0560 & 0.0734 & 0.2271 & 0.1362 & 0.0454 \\
\hline 0.2500 & 0.4794 & 0.4095 & 0.3395 & 0.1558 & 0.1030 & 0.0501 & 0.0382 & 0.0553 & 0.0725 & 0.2754 & 0.1902 & 0.1051 \\
\hline 0.3000 & 0.5570 & 0.4786 & 0.4003 & 0.1945 & 0.1353 & 0.0761 & 0.0371 & 0.0538 & 0.0705 & 0.3237 & 0.2442 & 0.1648 \\
\hline 0.3500 & 0.6284 & 0.5435 & 0.4586 & 0.2357 & 0.1716 & 0.1074 & 0.0356 & 0.0517 & 0.0677 & 0.3720 & 0.2982 & 0.2244 \\
\hline 0.4000 & 0.6937 & 0.6041 & 0.5146 & 0.2795 & 0.2118 & 0.1441 & 0.0338 & 0.0491 & 0.0643 & 0.4203 & 0.3522 & 0.2841 \\
\hline 0.4500 & 0.7529 & 0.6605 & 0.5682 & 0.3257 & 0.2559 & 0.1861 & 0.0318 & 0.0461 & 0.0604 & 0.4686 & 0.4062 & 0.3437 \\
\hline 0.5000 & 0.8059 & 0.7126 & 0.6194 & 0.3744 & 0.3039 & 0.2335 & 0.0295 & 0.0428 & 0.0561 & 0.5169 & 0.4602 & 0.4034 \\
\hline 0.5500 & 0.8529 & 0.7605 & 0.6682 & 0.4257 & 0.3559 & 0.2861 & 0.0270 & 0.0392 & 0.0514 & 0.5652 & 0.5141 & 0.4631 \\
\hline 0.6000 & 0.8937 & 0.8041 & 0.7146 & 0.4795 & 0.4118 & 0.3441 & 0.0244 & 0.0355 & 0.0465 & 0.6135 & 0.5681 & 0.5227 \\
\hline 0.6500 & 0.9284 & 0.8435 & 0.7586 & 0.5357 & 0.4716 & 0.4074 & 0.0217 & 0.0315 & 0.0413 & 0.6618 & 0.6221 & 0.5824 \\
\hline 0.7000 & 0.9570 & 0.8786 & 0.8003 & 0.5945 & 0.5353 & 0.4761 & 0.0189 & 0.0274 & 0.0359 & 0.7101 & 0.6761 & 0.6420 \\
\hline 0.7500 & 0.9794 & 0.9095 & 0.8395 & 0.6558 & 0.6030 & 0.5501 & 0.0159 & 0.0231 & 0.0303 & 0.7585 & 0.7301 & 0.7017 \\
\hline 0.8000 & 0.9958 & 0.9361 & 0.8764 & 0.7196 & 0.6745 & 0.6294 & 0.0129 & 0.0187 & 0.0245 & 0.8068 & 0.7841 & 0.7614 \\
\hline 0.8500 & 1.0060 & 0.9584 & 0.9109 & 0.7860 & 0.7500 & 0.7141 & 0.0098 & 0.0142 & 0.0186 & 0.8551 & 0.8380 & 0.8210 \\
\hline 0.9000 & 1.0101 & 0.9766 & 0.9430 & 0.8548 & 0.8294 & 0.8040 & 0.0066 & 0.0095 & 0.0125 & 0.9034 & 0.8920 & 0.8807 \\
\hline 0.9500 & 1.0081 & 0.9904 & 0.9727 & 0.9261 & 0.9127 & 0.8994 & 0.0033 & 0.0048 & 0.0063 & 0.9517 & 0.9460 & 0.9403 \\
\hline 1.0000 & 1.0000 & 1.0000 & 1.0000 & 1.0000 & 1.0000 & 1.0000 & 0.0000 & 0.0000 & 0.0000 & 1.0000 & 1.0000 & 1.0000 \\
\hline
\end{tabular}

Table 2: Representation of parabolic expression of equations 5, 6 and 7 


\begin{tabular}{|c|c|c|c|c|c|c|c|c|c|c|c|}
\hline Tender Code & ID & $\mathbf{N}$ & Dmin & Dm & Dmax & $\sigma$ & Do & Dmax est & Dmin est & $\sigma$ est & Do est \\
\hline СТ08001116 & 1 & 13 & 0.0000 & 0.1111 & 0.2013 & 0.0589 & 0.0700 & 0.1951 & 0.0337 & 0.0538 & 0.0403 \\
\hline СТ07002839 & 2 & 4 & 0.0010 & 0.0536 & 0.1149 & 0.0591 & 0.1280 & 0.0967 & 0.0138 & 0.0471 & -0.0218 \\
\hline СТ08000938 & 3 & 14 & 0.0100 & 0.0735 & 0.1476 & 0.0477 & & 0.1315 & 0.0201 & 0.0503 & \\
\hline СТ08000941 & 4 & 3 & 0.0902 & 0.1162 & 0.1643 & 0.0417 & & 0.2035 & 0.0357 & 0.0541 & \\
\hline СТ07002792 & 5 & 11 & 0.0000 & 0.0748 & 0.1353 & 0.0493 & -0.1670 & 0.1337 & 0.0205 & 0.0505 & 0.0011 \\
\hline СТ08000553 & 6 & 5 & 0.0000 & 0.0421 & 0.0803 & 0.0369 & -0.1800 & 0.0764 & 0.0105 & 0.0445 & -0.0343 \\
\hline СТ08000597 & 7 & 6 & 0.0515 & 0.0862 & 0.1515 & 0.0379 & 0.0010 & 0.1533 & 0.0244 & 0.0518 & 0.0134 \\
\hline СТ08000389 & 8 & 22 & 0.0514 & 0.1813 & 0.2732 & 0.0491 & 0.1170 & 0.3076 & 0.0649 & 0.0560 & 0.1161 \\
\hline СТ07003248 & 9 & 10 & 0.0000 & 0.0799 & 0.1501 & 0.0572 & & 0.1424 & 0.0222 & 0.0511 & \\
\hline СТ08000257 & 10 & 25 & 0.1002 & 0.1835 & 0.2508 & 0.0457 & 0.0330 & 0.3109 & 0.0660 & 0.0560 & 0.1184 \\
\hline СТ08000137 & 11 & 11 & 0.0539 & 0.1257 & 0.2500 & 0.0647 & & 0.2192 & 0.0395 & 0.0547 & \\
\hline СТ07003152 & 12 & 43 & 0.0092 & 0.1601 & 0.2860 & 0.0729 & & 0.2746 & 0.0547 & 0.0558 & \\
\hline СТ07003153 & 13 & 43 & 0.0517 & 0.1901 & 0.3009 & 0.0672 & & 0.3210 & 0.0693 & 0.0561 & \\
\hline СТ07002641 & 14 & 12 & 0.1861 & 0.2687 & 0.3505 & 0.0569 & & 0.4359 & 0.1146 & 0.0548 & \\
\hline СТ07002800 & 15 & 23 & 0.2015 & 0.2734 & 0.3610 & 0.0500 & & 0.4424 & 0.1176 & 0.0547 & \\
\hline СТ07002802 & 16 & 39 & 0.1571 & 0.2557 & 0.3500 & 0.0559 & & 0.4176 & 0.1064 & 0.0552 & \\
\hline СТ07003157 & 17 & 18 & 0.0370 & 0.1569 & 0.2525 & 0.0566 & & 0.2693 & 0.0531 & 0.0557 & \\
\hline СТ07002822 & 18 & 14 & 0.1028 & 0.1854 & 0.2367 & 0.0381 & 0.0700 & 0.3138 & 0.0670 & 0.0560 & 0.1205 \\
\hline СТ07002921 & 19 & 6 & 0.1818 & 0.2262 & 0.2833 & 0.0383 & & 0.3750 & 0.0889 & 0.0558 & \\
\hline СТ07002648 & 20 & 45 & 0.0003 & 0.1362 & 0.3282 & 0.0935 & & 0.2363 & 0.0440 & 0.0551 & \\
\hline СТ07002660 & 21 & 7 & 0.0290 & 0.0839 & 0.1555 & 0.0453 & 0.0040 & 0.1493 & 0.0236 & 0.0515 & 0.0109 \\
\hline СТ07002721 & 22 & 19 & 0.0950 & 0.1632 & 0.2436 & 0.0398 & & 0.2794 & 0.0561 & 0.0558 & \\
\hline СТ07002733 & 23 & 4 & 0.0100 & 0.0374 & 0.0675 & 0.0239 & -0.0630 & 0.0681 & 0.0092 & 0.0433 & -0.0393 \\
\hline СТ07002108 & 24 & 22 & 0.0955 & 0.1765 & 0.2390 & 0.0386 & 0.1210 & 0.3001 & 0.0625 & 0.0560 & 0.1109 \\
\hline СТ07002493 & 25 & 25 & 0.0500 & 0.2043 & 0.4062 & 0.0821 & & 0.3426 & 0.0768 & 0.0560 & \\
\hline СТ07002568 & 26 & 9 & 0.0625 & 0.0961 & 0.1600 & 0.0300 & & 0.1700 & 0.0280 & 0.0527 & \\
\hline СТ07001934 & 27 & 16 & 0.0325 & 0.1277 & 0.2200 & 0.0530 & 0.1120 & 0.2225 & 0.0404 & 0.0547 & 0.0582 \\
\hline СТ07001972 & 28 & 10 & 0.1550 & 0.2097 & 0.2800 & 0.0428 & & 0.3506 & 0.0797 & 0.0560 & \\
\hline
\end{tabular}




\begin{tabular}{|c|c|c|c|c|c|c|c|c|c|c|c|}
\hline СТ07002052 & 29 & 9 & 0.1489 & 0.2361 & 0.2985 & 0.0561 & & 0.3896 & 0.0947 & 0.0556 & \\
\hline СТ07001745 & 30 & 27 & 0.0103 & 0.1723 & 0.2818 & 0.0688 & & 0.2936 & 0.0605 & 0.0559 & \\
\hline СТ07001090 & 31 & 3 & 0.0000 & 0.0532 & 0.1200 & 0.0611 & & 0.0961 & 0.0137 & 0.0470 & \\
\hline СТ07001776 & 32 & 6 & 0.0025 & 0.0613 & 0.1090 & 0.0441 & & 0.1102 & 0.0162 & 0.0485 & \\
\hline СТ07001903 & 33 & 9 & 0.0105 & 0.0855 & 0.1500 & 0.0523 & 0.0350 & 0.1520 & 0.0242 & 0.0517 & 0.0126 \\
\hline СТ07001957 & 34 & 9 & 0.0100 & 0.1307 & 0.3741 & 0.1028 & 0.2830 & 0.2273 & 0.0416 & 0.0549 & 0.0614 \\
\hline СТ07001003 & 35 & 5 & 0.0192 & 0.0519 & 0.1001 & 0.0297 & & 0.0937 & 0.0133 & 0.0468 & \\
\hline СТ07001602 & 36 & 9 & 0.0374 & 0.1199 & 0.2450 & 0.0666 & & 0.2096 & 0.0371 & 0.0544 & \\
\hline СТ07001042 & 37 & 3 & 0.0000 & 0.0327 & 0.0582 & 0.0298 & & 0.0597 & 0.0079 & 0.0418 & \\
\hline СТ06002801 & 38 & 12 & 0.0680 & 0.1792 & 0.3414 & 0.0860 & & 0.3043 & 0.0638 & 0.0560 & \\
\hline СТ07001376 & 39 & 5 & 0.0321 & 0.0699 & 0.1102 & 0.0277 & & 0.1252 & 0.0189 & 0.0498 & \\
\hline СТ07000948 & 40 & 12 & 0.0105 & 0.1348 & 0.2079 & 0.0548 & & 0.2340 & 0.0433 & 0.0550 & \\
\hline СТ07000957 & 41 & 8 & 0.0576 & 0.0947 & 0.1452 & 0.0256 & & 0.1677 & 0.0275 & 0.0526 & \\
\hline СТ07001150 & 42 & 20 & 0.0000 & 0.1363 & 0.2641 & 0.0621 & & 0.2365 & 0.0440 & 0.0551 & \\
\hline СТ07000938 & 43 & 11 & 0.0000 & 0.0849 & 0.2114 & 0.0749 & & 0.1510 & 0.0240 & 0.0516 & \\
\hline СТ07000944 & 44 & 4 & 0.0212 & 0.0676 & 0.1233 & 0.0457 & & 0.1212 & 0.0182 & 0.0495 & \\
\hline СТ07000884 & 45 & 5 & 0.0121 & 0.0885 & 0.1700 & 0.0661 & & 0.1571 & 0.0252 & 0.0520 & \\
\hline & & & & & & & R: & 0.8885 & 0.8476 & 0.4310 & 0.5400 \\
\hline & & & & & & & $\mathbf{R}^{\wedge} 2:$ & 0.7895 & 0.7185 & 0.1858 & 0.2916 \\
\hline
\end{tabular}

Table 3: Calculations of Correlation Factor (R) and Quadratic Correlation Factor (R2) for each Parabolic regression curve 


\section{Acknowledgements}

The translation of this paper was funded by the Universidad Politécnica de Valencia

\section{References}

Ballesteros-Pérez, P, 2010. Doctoral thesis: "Propuesta de un nuevo modelo para la predicción de bajas en licitaciones de Construcción" ('Proposal of a new model for Bid Tender Forecasting in Construction Tendering'). González Cruz, MC. dir. ; Pastor Ferrando, JP. dir. . Universal Identifier: http://hdl.handle.net/10251/7025 (pdf available on line)

Ballesteros-Pérez, P., González-Cruz, Mª . C., Pastor-Ferrando, J.P. and Fernández-Diego, M. The iso-Score Curve Graph. A new tool for competitive bidding, Automation in Construction (2011) doi:10.1016/j.autcon.2011.11.007

Carr, R.I., 1982. General bidding model Journal of the Construction Division, Proceedings of the American Society of Civil Engineers. 108 (CO4), 639-50.

Chang, A.S., 2001. Defining Cost/Schedule Performance Indices and Their Ranges for Design Projects. Journal of Management in Engineering. 17, 122-130.

Chao, L. and Liou, C., 2007. Risk-minimizing approach to bid-cutting limit determination. Construction Management and Economics. 25 (8), 835-843.

Deltas, G. and Engelbrecht-Wiggans, R., 2005. Naive Bidding. Management Science. 51 (3), 328-338.

Dikmen, I., Talat, M. and Kemal, A., 2007. A case-based decision support tool for bid markup estimation of international construction projects Automation in Construction, 17 (1) 30-44.

Drew, D. and Skitmore, R.M., 1997. The effect of contract type and size on competitiveness in bidding. Construction Management and Economics. 15, 469-489.

Engelbrecht-Wiggans, R., 1980. State of the Art-Auctions and Bidding Models: A Survey. Management Science. 26 (2), 119-142.

Engelbrecht-Wiggans, R., 1989. The Effect of Regret on Optimal Bidding in Auctions. Management Science. 35 (6), 685-692.

Fayek, A., 1998. Competitive bidding strategy model and software system for bid preparation. Journal of Construction Engineering and Management. 124, 1-10. 
Friedman, L., 1956. A competitive bidding strategy Operations Research 1 (4), 104-12.

Gates, M., 1967. Bidding strategies and probabilities Journal of the Construction Division, Proceedings of the American Society of Civil Engineers. 93 (CO1), 75-107.

Harstad, R.M. and Saša Pekec, A., 2008. Relevance to Practice and Auction Theory: A Memorial Essay for Michael Rothkopf. Interfaces. 38 (5) 367-380.

Hartono, B. and Yap, C.M., 2011. Understanding risky bidding: a prospect-contingent perspective Construction Management and Economics. 29 (6), 579-593.

Hong, C., 2004. Contractor Performance Prediction Model for the United Kingdom Construction Contractor: Study of Logistic Regression Approach. Journal of Construction Engineering and Management. 130, 691-698.

Laryea, S. and Hughes, W., 2011. Risk and Price in the Bidding Process of Contractors Journal of Construction Engineering and Management. 137 (4), 248-259.

Lo, W.; Lin, C.L. and Yan, M.R., 2007. Contractor's Opportunistic Bidding Behavior and Equilibrium Price Level in the Construction Market. Journal of Construction Engineering and Management. 133 (6), 409-416.

Lowe, D.J., Emsley, M.W. and Harding, A., 2006. Predicting Construction Cost Using Multiple Regression Techniques. Journal of Construction Engineering and Management. 132, 750-758.

McCaffer, R. and Pettitt, A.N., 1976. Distribution of bids for buildings and road contracts Operational Research Quarterly. 27 (4i), 835-43.

Mitchell, M.S., 1977. The probability of being the lowest bidder Applied Statistics 2 (2), 1914.

Mohamed, K.A., Khoury, S.S. and Hafez, S.M., 2011. Contractor's decision for bid profit reduction within opportunistic bidding behavior of claims recovery International Journal of Project Management. 29 (1), 93-107.

Naoum, S.G., 1994. Critical Analysis of Time and Cost of Management and Traditional Contracts. Journal of Construction Engineering and Management. 120 (4), 687-705.

Näykki, P., 1976. On Optimal Bidding Strategies. Management Science. 23 (2), 198-203. 
Oo, B., Drew, D.S. and Runeson, G., 2010. Competitor analysis in construction bidding Construction Management and Economics, 28 (12), 1321-1329.

Oo, B.L., Drew, D.S. and Lo, H.P., 2008. A comparison of contractors' decision to bid behaviour according to different market environments International Journal of Project Management. 26 (4), 439-447.

Oo, B.L., Drew, D.S. and Lo, H.P., 2008. Heterogeneous Approach to Modeling Contractors' Decision-to-Bid Strategies Journal of Construction Engineering and Management. 134 (10), 766-776

Pellicer, E., 2005. Cost Control in Consulting Engineering Firms. Journal of Management in Engineering. 21, 189-192.

Pim, J.C., 1974. Competitive tendering and bidding strategy National Builder. 55 (11), 541545.

Remer, D.S. and Buchanan, H.R., 2000. Estimating the cost for doing a cost estimate. International Journal of Production Economics. 66, 101-104.

Rothkopf, M.H., 1969. A Model of Rational Competitive Bidding. Management Science. 15 (7) 362-373.

Rothkopf, M.H. and Harstad, R.M., 1994. Modeling Competitive Bidding: A Critical Essay. Management Science. 40 (3), 364-384.

Runeson, K.G. and Skitmore, R.M., 1999. Tendering theory revisited Construction Management and Economics. 17 (3), 285-96.

Shapiro, S. S., Wilk, M. B., 1965. An analysis of variance test for normality (complete samples). Biometrika 52 (3-4) 591-611.

Skitmore, R.M., 1991. The contract bidder homogeneity assumption: an empirical analysis. Construction Management and Economics. 9 (5), 403-429.

Skitmore, R.M., 2002. The probability of tendering the lowest bid in sealed auctions: an empirical analysis of construction data. Journal of the Operational Research Society. 53 (1), 47-56.

Skitmore, R.M., 2004. Predicting the probability of winning sealed bid auctions: the effects of outliers on bidding models. Construction Management and Economics. 22 (1), $101-109$. 
Skitmore, R.M., 2008. First and second price independent values sealed bid procurement auctions: some scalar equilibrium results Construction Management and Economics. 26 (8), 787-803.

Skitmore, R.M., Drew, D.S. and Ngai, S., 2001. Bid-spread. Journal of Construction Engineering and Management. 127 (2), 149-153.

Skitmore, R.M. and Runeson, G., 2006. Bidding models: testing the stationarity assumption Construction Management and Economics. 24 (8), 791-803.

Skitmore, R.M., Pettitt, A.N. and McVinish, R., 2007. Gates' Bidding Model. Journal of Construction Engineering and Management. 133 (11), 855-863.

Stark, R.M. and Rothkopf, M.H., 1979. Competitive bidding: A comprehensive bibliography. Journal of the Operational Research. 27 (2), 364-390.

Thomas, S., Ng., A; Cheung., B.S.O.; Skitmore, R.M., Toby, C. and Wong, Y., 2004. An integrated regression analysis and time series model for construction tender price index forecasting. Construction Management and Economics. 22, 483 - 493.

Touran, A., 1993. Probabilistic Cost Estimating with Subjective Correlations. Journal of Construction Engineering and Management. 119, 58-71.

Touran, A. and Lopez, R., 2006. Modeling Cost Escalation in Large Infrastructure Projects. Journal of Construction Engineering and Management. 132, 853-860.

Trost, S.M. and Oberlender, G.D., 2003. Predicting Accuracy of Early Cost Estimates Using Factor Analysis and Multivariate Regression. Journal of Construction Engineering and Management. 129, 198-204.

Watt, D.J., Kayis, B. and Willey, K., 2009. Identifying key factors in the evaluation of tenders for projects and services. International Journal of Project Management. 27 (3), 250-260.

Ye, K.; Jiang, W. and Shen, L., 2008. Project competition intensity (PCI) in the construction market: a case study in China. Construction Management and Economics. 26 (5) 463-470. 